\title{
Investigation of the Thermal Profile of a Crop Dryer Powered by Generator Exhaust Gas Waste Heat
}

\author{
C. Ononogbo ${ }^{1}$, O.C. Nwufo ${ }^{2}$, G.N. Nwaji ${ }^{2}$, E. C.Nwosu ${ }^{2}$, P. C. Nwadinobi ${ }^{3}$, \\ C.A. Okoronkwo ${ }^{2}$, J.O. Igbokwe' ${ }^{2}$, E.E. Anyanwu ${ }^{2}$ \\ ${ }^{*} 1$ Department of Mechanical Engineering, University of Agriculture and Environmental Sciences, \\ Umuagwo. P.M.B. 1472 Owerri, Imo State, Nigeria \\ 2Department of Mechanical Engineering, Federal University of Technology, \\ P.M.B. 1526 Owerri, Imo State, Nigeria \\ ${ }^{3}$ Department of Mechanical Engineering, Abia State University, Uturu, \\ P.M.B. 2000, Abia State, Nigeria
}

\begin{abstract}
The thermal profile of an exhaust gas waste heat recovery (WHR) crop dryer is presented. The dryer uses a parallel flow heat exchanger to recover the exhaust gas waste heat of a diesel engine generator for the drying of food crops. No-load tests of the assembled test rig were conducted to study the temperature profile and heat transfer rates in the dryer at varying inlet ambient air velocities. The results of the no-load tests revealed that the higher the airspeed through the WHR heat exchanger, the faster the rate of heating of the drying chamber. It was observed that the drying chamber initially at $32.3^{\circ} \mathrm{C}$, was heated to a maximum temperature of $116.1{ }^{\circ} \mathrm{C}$ after only a period of $39 \mathrm{~min}$ at an air velocity of $2 \mathrm{~m} / \mathrm{s}$. The values of the heat transfer rate obtained at selected drying chamber temperatures showed that the higher the drying chamber temperature, the lower the value of the heat transfer rate. The dryer was successfully used to dry freshly harvested maize grains and blanched yam samples at varying drying air temperatures and velocities. The results obtained will be very useful in the design and development of eco-friendly commercial dryers powered by recovered waste heat from available sources.
\end{abstract}

KEYWORDS: Waste heat recovery; heat transfer rate; drying; temperature profile; pollution

https://doi.org/10.29294/IJASE.8.3.2022.2235-2241 CC2022 Mahendrapublications.com, All rights reserved

\section{INTRODUCTION}

As human population and urbanization grow, there is a concomitant increase in energy use that translates into significant increases in fuel costs $[1,2]$. Diminishing supplies of petroleum and progressive rise in fuel prices are influencing governments and industries to seek for ways of improving the energy efficiency of engines [2, 3]. Woolley et al. [4] reported that up to one third of the global energy consumption is attributable to the industrial sector, with about fifty percent mainly wasted as heat. Waste heat recovery (WHR) is an important method of achieving reduction in energy wastes and the emission of greenhouse gases [5]. In recent times, considerable efforts are made towards the reduction of the quantity of energy dumped into the environment from internal combustion engines; and the main objective is to assist in conserving finite resources of fossil fuels, to reduce carbon footprint and combat climate change as well as improve process economics [2, $6,7]$. To reduce overdependence on fossil fuels and minimize their impact on the environment which manifests as pollutant emissions, Woolley et al. [4] noted that manufacturers should prioritize on the use of renewable energy systems or the reduction of energy consumption using WHR techniques. WHR using available technologies can provide valuable energy sources, thus improving overall energy efficiency $[6,8]$. In food processing industries, large quantity of waste heat is dumped into the environment during production activities, which has a significant effect on both energy costs during production and the price of finished products. However, improved energy conversion and utilization in these plants will not only reduce the cost of energy consumption, but will also contribute immensely to the preservation of the environment from excessive pollution. Furthermore, in tropical locations such as Africa, there is low rate of growth in food production which can be attributed to the poor level of food preservation practice, as farmers rely mostly on open air drying for crop preservation due to high energy costs associated with conventional drying systems. It is noteworthy that during postharvest periods, sizable quantities of crops perish because of storage problems; and the wastes are more 
pronounced during the rainy seasons when the prevailing solar energy intensity is low and the relative humidity is very high. Besides, some crops are associated with prolonged drying periods with optimum drying conditions that need huge amount of energy, resulting in elevated overhead drying costs and high prices of dried food products [9 -12]. Consequently, many farmers are discouraged from going into large-scale production of farm produce due to fear of crop wastes, and this greatly threatens food security. However, to minimize losses of agricultural products after harvest and thereby increase value and the profit margin of farmers, an inexpensive drying technique is necessary for freshly harvested food crops. This will help the food materials to be adequately dried and stored to ensure availability and wholesomeness all year round. One method of achieving this is by the use of a WHR dryer. To actualize this, a tray dryer powered by generator exhaust gas waste heat for the drying of food crops was designed and developed by Ononogbo et al. [2]. The equipment comprises two stages of waste energy recovery from the exhaust gas. In the first stage, the exhaust gas waste energy is harnessed by an axial flow turbine to drive a dynamo that generates electricity (to power the electrical components of the dryer such as the air blower, temperature and weight sensors, etc) before entering the heat exchanger. The second stage involves heating of the ambient air (drawn into the shell of a heat exchanger) by the exhaust gas passing through the tube of the heat exchanger. The heated air is then channeled to the drying chamber for the drying of food crops. However, in the recent work, the turbine-dynamo unit previously used for electricity generation to run the electrical devices of the dryer was completely replaced by an alternative source of power (solar panel) as shown in Figs. 1 and 2.

The use of the solar panel was due to the observed reduction of the exhaust gas quality by first passing it through the turbine for electricity generation, which lowers its capacity to raise the temperature of the drying air passing through the heat exchanger to an appreciable level.

This study investigated the thermal profile of the tray dryer to ascertain the temperature progression in the drying chamber and the heat transfer rate at some selected drying chamber temperatures for different inlet air velocities.

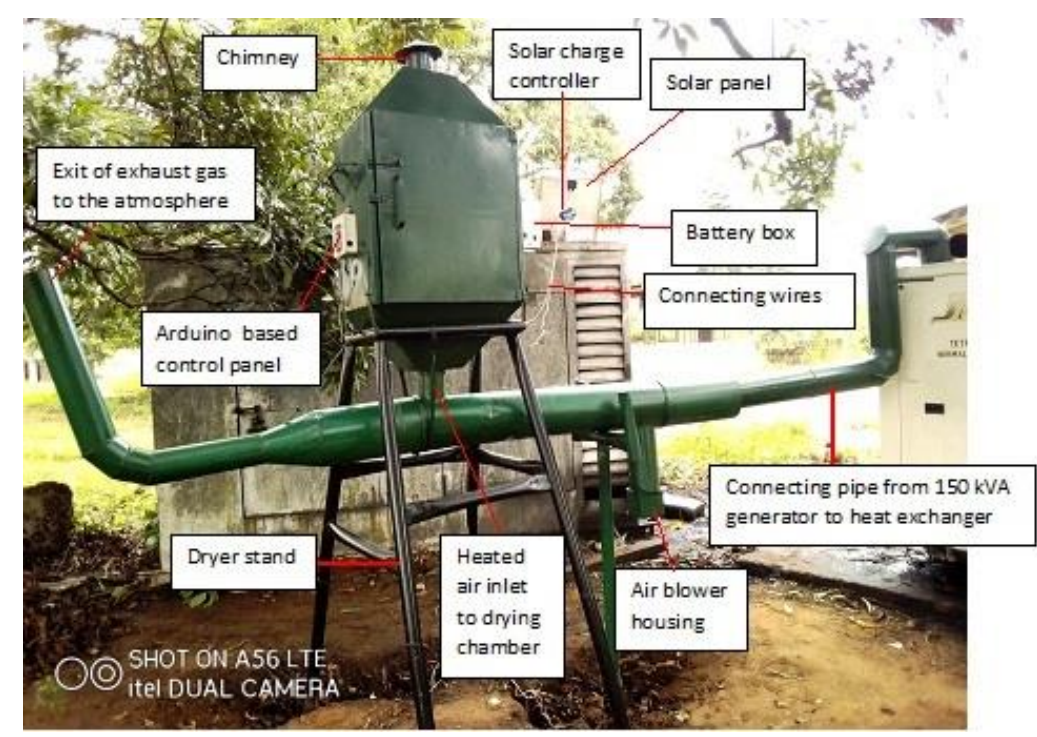

Fig. 1: Crop dryer connected to a $150 \mathrm{kVA}$ generator

\subsection{MATERIALS AND METHODS}

\subsection{Experimental procedure}

The test rig was installed to a $150 \mathrm{kVA}$ generator as shown in Fig. 1 and was subjected to tests without load in order to investigate the temperature profile across the dryer trays at varying drying air velocities (1.0, 1.5 and $2.0 \mathrm{~m} / \mathrm{s})$. The test rig of the dryer was subjected to no-load tests in order to investigate the temperature progressions at the trays every three (3) minutes.
The dryer has three wire mesh trays $(660 \mathrm{~mm} \mathrm{x}$ $470 \mathrm{~mm}$ ) positioned at different heights in the drying chamber. DHT11 temperature sensors (20 $\mathrm{mA}, 5 \mathrm{~V}$ each) were attached to the trays to measure the temperature values of the hot air. A temperature sensor was also kept outside the dryer to measure the ambient air temperature. The speed of the air was measured using a 20004 AHYK hot wire anemometer. An Arduino-based control panel was used to monitor and regulate 
the operations of the components of the dryer such as the air blower and temperature sensors, as well as record the values of the measurable parameters. The heat transfer rates from the exhaust gas to the drying air were also studied at selected drying chamber temperatures and inlet air velocities. Pertinent information from the literature shows that many food crops are dried with air temperatures in the range of $50-80^{\circ} \mathrm{C}$ and velocities ranging from 0.5-4 $\mathrm{m} / \mathrm{s}$ [13-17]. However, in this study the drying chamber temperatures selected were 50, 55, 60, 65 and $75^{\circ} \mathrm{C}$, across inlet air velocities of $1.0,1.5$ and 2.0 $\mathrm{m} / \mathrm{s}$, respectively.

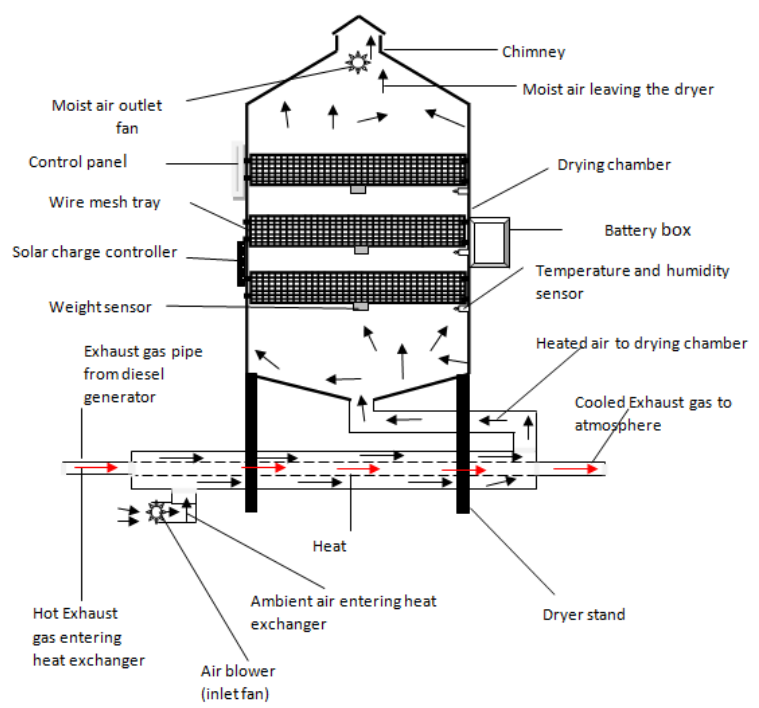

Fig. 2: Schematic diagram of the tray dryer Source: Ononogbo et al. [2]

\section{Determination of the heat transfer rate}

The heat transfer rate between the exhaust gas and the drying air, $Q_{r}(\mathrm{~J} / \mathrm{s})$ is calculated using Eq. (1) $[12,18]$ :

$$
\mathrm{Q}_{\mathrm{r}}=\mathrm{hA} \mathrm{he}_{\mathrm{he}}\left(\mathrm{t}_{\mathrm{s}}-\mathrm{t}_{\mathrm{b}}\right)
$$

where $h$ is the heat transfer coefficient $\left(\mathrm{W} / \mathrm{m}^{2}{ }^{\circ} \mathrm{C}\right)$, $A_{h e}$ is the surface area of the heat exchanger $\left(0.5036 \mathrm{~m}^{2}\right), t_{s}$ is the surface temperature of the heat exchanger tube (measured as $254.5^{\circ} \mathrm{C}$ ), $t_{b}$ is the mean bulk temperature $\left({ }^{\circ} \mathrm{C}\right)$ which can be obtained using Eq. (2) [18]:

$$
t_{b}=\frac{\left(t_{i}+t_{0}\right)}{2}
$$

where $t_{i}$ is the inlet temperature of air into the heat exchanger, and $t_{0}$ is the drying air (chamber) temperature.

The heat transfer coefficient $(h)$ was obtained using Eq. (3) [19]
$\mathrm{h}=\frac{\mathrm{N}_{\mathrm{u}} \mathrm{k}}{\mathrm{D}}$

where $N_{u}$ is the Nusselt number, $D$ is the diameter of heat exchanger $(0.1 \mathrm{~m})$ and $k$ is the thermal conductivity $(\mathrm{W} / \mathrm{mK})$ of air evaluated at the mean bulk temperature. The Nusselt number $N_{u}$ was obtained using Eq. (4) which is the correlation of turbulent flows for heating of fluids in circular tubes [18]:

$$
N_{u}=0.023\left(R_{e}\right)^{0.8}\left(P_{r}\right)^{0.4}
$$

where $P_{r}$ is the $\operatorname{Pr}$ and tl number, and $R_{e}$ is the Reynolds number obtained using Eq. (5) [20]:

$$
\mathrm{R}_{\mathrm{e}}=\frac{\rho_{\mathrm{a}} \mathrm{v}_{\mathrm{a}} \mathrm{D}}{\mu_{\mathrm{s}}}
$$

where all the properties of air were evaluated at the mean bulk temperature $\left(t_{b}\right)$ except for the dynamic viscosity, $\mu_{s}(\mathrm{~kg} / \mathrm{ms})$ which was evaluated at the surface temperature $\left(t_{s}\right) \cdot \mathrm{v}_{\mathrm{a}}$ is the air velocity $(\mathrm{m} / \mathrm{s})$, and $\rho_{\mathrm{a}}$ is the air density $\left(\mathrm{kg} / \mathrm{m}^{3}\right)$.

\subsection{RESULTS AND DISCUSSION}

The resulting temperature profile as shown in Table 1 is such that the higher the velocity of air passing through the heat exchanger, the higher the heating effectiveness of the drying air. At higher velocities, more air was inducted into the heat exchanger resulting in more evacuation of heat from the exhaust gas at the heat exchanger. From Figs. 3 to 5 , it could be easily seen during the no load test that for each of the drying trays, it took the drying air the shortest time duration to reach the highest temperature at $2.0 \mathrm{~m} / \mathrm{s}$, while the longest duration of time was recorded for the lowest air speed of $1.0 \mathrm{~m} / \mathrm{s}$. At the drying air velocity of $1 \mathrm{~m} / \mathrm{s}$, the temperatures of the topmost tray $\left(T_{1}\left({ }^{\circ} \mathrm{C}\right)\right)$, middle tray $\left(T_{2}\left({ }^{\circ} \mathrm{C}\right)\right)$ and bottom tray $\left(T_{3}\left({ }^{\circ} \mathrm{C}\right)\right)$ increased from the ambient temperature of $31^{\circ} \mathrm{C}$ to $107.3,105.2$ and $101.4{ }^{\circ} \mathrm{C}$ after 48 mins, respectively. At $1.5 \mathrm{~m} / \mathrm{s}$, the values were $111.0,111.3$ and $107.5{ }^{\circ} \mathrm{C}$ in 48 mins. While for a velocity of $2 \mathrm{~m} / \mathrm{s}$, the temperature values were $116.1,114.9$ and $114.5{ }^{\circ} \mathrm{C}$ in 39 mins, respectively as shown in Table 1 . Throughout the no load experiment for the various air velocities, the temperature of tray 3 (bottom tray) remained the least value among the temperatures of the three trays kept at different positions along the height of the drying chamber. Towards the end of the no load test for each drying air speed, it was observed that the temperatures of the trays remained fairly constant. 
Table 1: Average values of temperature profile for no load test of the dryer for the three drying trays at varying air velocities

- $\quad$ Average ambient temperature: $32.1^{\circ} \mathrm{C}$

- Average ambient humidity $-52 \%$

\begin{tabular}{|c|c|c|c|c|c|c|c|c|c|}
\hline \multirow{3}{*}{$\begin{array}{l}\text { Time } \\
\text { (min) }\end{array}$} & \multicolumn{9}{|c|}{ Air velocity (m/s) } \\
\hline & \multicolumn{3}{|c|}{1.0} & \multicolumn{3}{|c|}{1.5} & \multicolumn{3}{|c|}{2.0} \\
\hline & $T_{1}\left({ }^{\circ} \mathrm{C}\right)$ & $\begin{array}{c}T_{2} \\
\left({ }^{\circ} \mathrm{C}\right)\end{array}$ & $\begin{array}{c}T_{3} \\
\left({ }^{\circ} \mathrm{C}\right)\end{array}$ & $T_{1}\left({ }^{\circ} \mathrm{C}\right)$ & $\begin{array}{c}T_{2} \\
\left({ }^{\circ} \mathrm{C}\right)\end{array}$ & $\begin{array}{c}T_{3} \\
\left({ }^{\circ} \mathrm{C}\right)\end{array}$ & $\begin{array}{c}T_{1} \\
\left({ }^{\circ} \mathrm{C}\right)\end{array}$ & $\begin{array}{c}T_{2} \\
\left({ }^{\circ} \mathrm{C}\right)\end{array}$ & $\begin{array}{c}T_{3} \\
\left({ }^{\circ} \mathrm{C}\right)\end{array}$ \\
\hline $\mathbf{0}$ & 32.1 & 32.1 & 32.1 & 31.9 & 31.9 & 31.9 & 32.3 & 32.3 & 32.3 \\
\hline 3 & 49.6 & 48.9 & 48.5 & 69.3 & 68.6 & 62.2 & 71.3 & 70.3 & 69.6 \\
\hline 6 & 66.4 & 64.8 & 62.6 & 82.5 & 80.1 & 75.6 & 91.1 & 89.6 & 88.1 \\
\hline 9 & 77.2 & 74.8 & 72.2 & 89.6 & 90.1 & 84.8 & 101.1 & 99.7 & 98.3 \\
\hline 12 & 83.8 & 81.4 & 78.5 & 95.7 & 95.3 & 90.9 & 106.2 & 104.4 & 103.8 \\
\hline 15 & 88.7 & 86.1 & 83.2 & 98.9 & 98.6 & 94.1 & 109.8 & 108.3 & 106.9 \\
\hline 18 & 92.9 & 90.3 & 87.6 & 100.8 & 100.6 & 96.2 & 112.2 & 110.8 & 109.8 \\
\hline 21 & 96.7 & 94.1 & 91.1 & 102.9 & 103.0 & 98.6 & 113.3 & 112.0 & 111.1 \\
\hline 24 & 97.8 & 95.1 & 92.1 & 104.1 & 104.2 & 99.9 & 114.1 & 112.8 & 112.0 \\
\hline 27 & 99.5 & 97.3 & 93.8 & 104.8 & 104.8 & 100.8 & 114.6 & 113.5 & 112.4 \\
\hline 30 & 101.2 & 99.3 & 96.5 & 105.4 & 105.6 & 101.6 & 115.1 & 113.9 & 113.0 \\
\hline 33 & 102.9 & 100.5 & 97.3 & 106.8 & 107.1 & 102.8 & 115.6 & 114.3 & 113.9 \\
\hline 36 & 104.8 & 101.2 & 99.5 & 108.3 & 108.7 & 104.3 & 116.0 & 114.9 & 114.3 \\
\hline 39 & 105.1 & 102.8 & 100.1 & 109.3 & 109.5 & 105.6 & 116.1 & 114.9 & 114.5 \\
\hline 42 & 105.7 & 103.0 & 100.4 & 109.9 & 110.5 & 106.5 & 116.1 & 114.9 & 114.5 \\
\hline 45 & 106.1 & 103.5 & 100.8 & 111.0 & 111.2 & 106.9 & 116.1 & 114.9 & 114.5 \\
\hline 48 & 107.3 & 105.2 & 101.4 & 111.0 & 111.3 & 107.5 & 116.1 & 114.9 & 114.5 \\
\hline
\end{tabular}

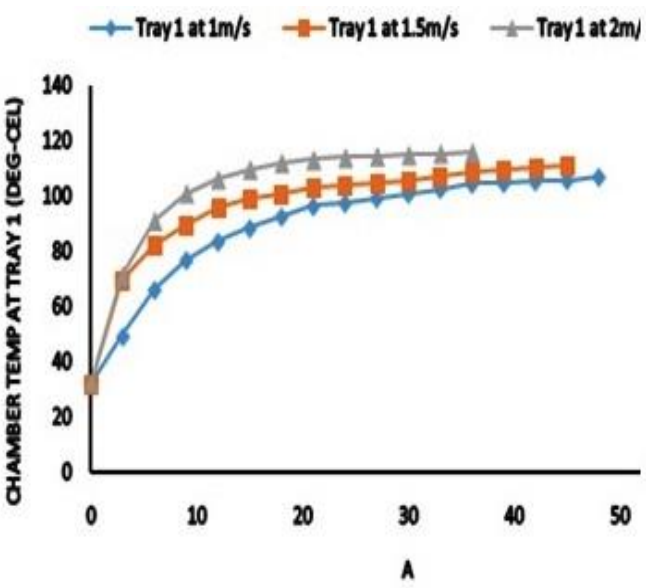

Fig. 3: Temperature profile of the drying chamber at the topmost tray

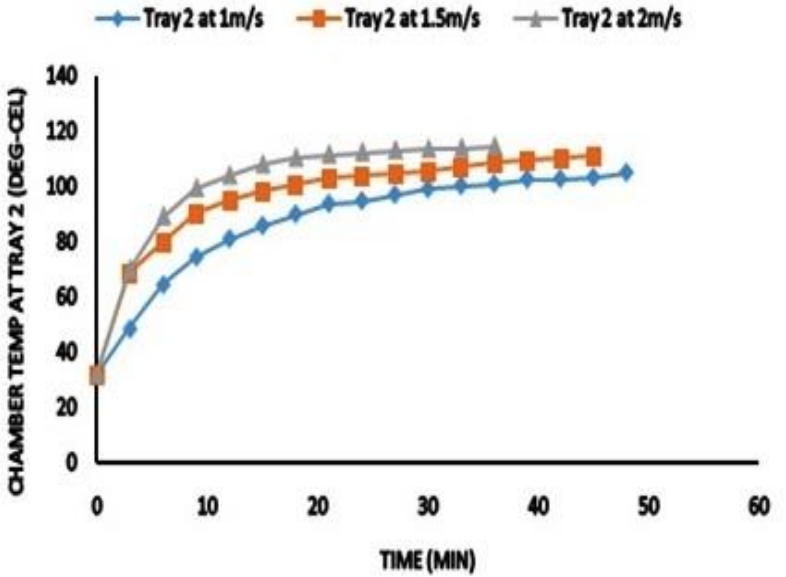

Fig. 4: Temperature profile of the drying chamber at the middle tray 


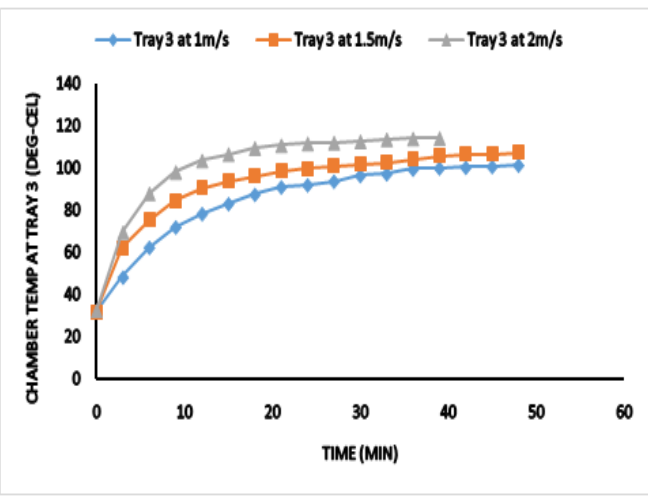

Fig. 5: Temperature profile of the drying chamber at the bottom tray

Thus, about the period of 42 minutes, the rate of heating of the chamber trays became very slow, thereby showing that the drying chamber had reasonably reached its peak temperature at the various air velocities. Furthermore, for each of the air velocities, it was observed that among the three trays, the tray closest to the heat source recorded the least temperature values (for the three air velocity levels), although it was initially believed to be the hottest. The reason was as a result of convection current taking place in the drying chamber, causing hotter and lighter air to move up the chamber, and colder and heavier air to move down the chamber. In addition, from Table 1, the changes in temperature between trays 1 and 2 were irregular in the sense that at some points, the temperature of tray 1 was slightly higher while that of tray 2 was lower and vice versa. The inlet temperature of the exhaust gas at the inlet of the heat exchanger was $305{ }^{\circ} \mathrm{C}$, while the average temperature of the exhaust gas at the outlet of the heat exchanger for the three air velocity levels was $189^{\circ} \mathrm{C}$. This shows that more heat is still available to be transferred from the exhaust to the air passing through the heat exchanger to the drying chamber, whose highest temperature in the chamber was $116.1{ }^{\circ} \mathrm{C}$. Thus revealing that the dryer can be scaled- up by increasing the length of the heat exchanger and the capacity of its drying chamber for more crops to be accommodated during drying. Increasing the length of the heat exchanger will certainly improve the residence time of the drying air in the heat exchanger for more heat transfer to occur.

The tendency of heat transfer from the exhaust gas to the air passing through the heat exchanger at elevated chamber temperatures is lower compared to that at lower chamber temperatures. From Fig. 6, it is obvious that the higher the selected drying air temperature in the drying chamber, the lower the values of the heat transfer rate. This is due to the lower temperature gradient between the heated air and the exhaust gas, as temperature difference influences the rate at which heat is transferred between gaseous steams. Conversely, the higher the inlet ambient air velocity into the heat exchanger, the higher the heat transfer rate. The highest value of the heat transfer rate $(904 \mathrm{~kJ} / \mathrm{s})$ was achieved at the lowest chamber temperature of $50{ }^{\circ} \mathrm{C}$ and highest air velocity of $2 \mathrm{~m} / \mathrm{s}$, whereas the lowest value (481 $\mathrm{kJ} / \mathrm{s}$ ) was obtained at the highest chamber temperature of $75{ }^{\circ}$ Cand lowest air velocity of 1 $\mathrm{m} / \mathrm{s}$. Therefore, it could be surmised that the higher the drying chamber temperature, the lower the rate of heat transfer from the exhaust gas to the drying air.

The experimental investigation of the original setup of the WHR tray dryer as reported by Ononogbo et al. (2020) at no load showed that the drying chamber was heated from 31 to $88 \stackrel{\circ}{\circ}$ after $45 \mathrm{~min}$ for an inlet air velocity of $2.0 \mathrm{~m} / \mathrm{s}$. Obviously, the rate of heating of the drying chamber was much slower when compared with the results obtained in the recent setup where the drying chamber was heated from 32.3 to $116.1^{\circ} \mathrm{C}$ after only a period of $39 \mathrm{~min}$ at the same inlet air velocity of $2 \mathrm{~m} / \mathrm{s}$ as shown in Table 1 . The slower rate of heating of the drying chamber in the previous setup was because the exhaust gas was first utilized in driving the turbine-dynamo arrangement for electricity generation before passing through the heat exchanger for the heating of the drying air. Thus experiencing a reduction in its quality which rendered it incapable of providing sufficient heating effect to the drying air when compared with the recent setup which replaced the turbine unit with solar electricity. This is because in the previous setup, a sizable portion of the waste heat of the exhaust gas was converted to mechanical work when the exhaust gases impinged on the turbine blades for electricity production, thereby causing the energy available for ambient air heating to be appreciably reduced.

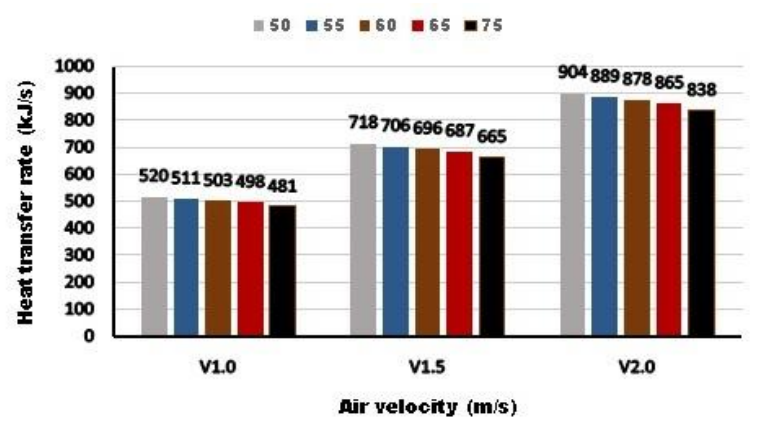

Fig. 6: Heat transfer rate at the selected chamber temperatures across and air velocities

Ononogbo et al., 


\section{Importance of the study to the food and energy sectors}

The appreciation of the connection between the food and energy sectors is very critical, as it relates to their influence on climate change and human comfort. It is pertinent to note that the preservation of food crops from damage after harvest requires energy to ensure their availability and wholesomeness all year round [21]. In addition, agro-food industries also require huge quantity of energy during food processing activities. However, the high price of fuels needed for optimum running of conventional crop dryers discourage many farmers in developing economies from going into large scale farming, especially during rainy periods. This is because wet season is associated with high relative humidity and low solar energy intensity, which hardly supports effective drying, and hence causes farmers who rely only on open sun drying to lose large quantities of their crops to wastes. This situation in no small way threatens food security. Besides, in developed economies where farmers have access to conventional crop dryers and the funds to run them, they still battle with the problem of increasing the price of dried products (due to high overhead drying costs) in order to improve their profit margin. Food processing industries are also not left out in this ugly trend as they must make profits to cushion the effects of high production expenses.

Interestingly, this research area will be very helpful in supporting efforts geared towards the promotion of food security, sustainable agriculture, and environment-friendly anthropogenic activities, which are very essential for human well-being. The work considers the recovery and application of the waste heat of exhaust gases to food crops drying, rather than the combustion of fresh fossil fuel to actualize the same purpose. This approach assists immensely in cost saving and minimizes environmental pollution. The dryer was successfully used to dry samples of maize grains and yam slices at varying conditions of the drying air. The recovery and utilization of waste heat from various sources for the drying of farm products will be useful in the promotion of sustainable agriculture, economic growth and protection of the natural environment. It will also be useful in protecting fossil fuel reserves from rapid depletion.

\section{CONCLUSION}

The thermal profile of the WHR dryer has been studied. The results obtained showed that the dryer can be conveniently enlarged for the purpose of commercialization. The average temperature of the exhaust gas at the exit of the heat exchanger $\left(189^{\circ} \mathrm{C}\right)$ reveals that sufficient heat is still available for more heat to be transferred to the air passing through the heat exchanger to the drying chamber. Hence, the chamber can be heated above the highest recorded temperature $\left(116.1^{\circ} \mathrm{C}\right)$ by increasing the length of the heat exchanger so as to raise the resident time of both the exhaust gas and the drying air in the heat exchanger. This will enable the scale up of the holding capacity of the drying chamber to accommodate more crops for drying at suitable drying air temperatures. The presented results were achieved without the thermal insulation of the heat exchanger and the pipe connecting the heat exchanger to the exhaust gas tailpipe of the generator. Therefore, to improve the heat transfer rate and effective heating of the drying chamber, it is recommended that these parts be properly lagged to prevent excessive dissipation of useful heat of the exhaust gas to the surrounding air.

\section{Nomenclature}

$A_{h e} \quad$ Surface area of heat exchanger $\left(\mathrm{m}^{2}\right)$

$D \quad$ Diameter of heat exchanger $(\mathrm{m})$

$h \quad$ Heat transfer coefficient $\left(\mathrm{W} / \mathrm{m}^{2}{ }^{\circ} \mathrm{C}\right)$

$k \quad$ Thermal conductivity $(\mathrm{W} / \mathrm{mK})$

$N_{u} \quad$ Nusselt number

$P_{r} \quad$ Prandtl number

$Q_{r} \quad$ Heat transfer rate $(\mathrm{J} / \mathrm{s})$

$R_{e} \quad$ Reynolds number

$t_{0} \quad$ Drying air (chamber) temperature $\left({ }^{\circ} \mathrm{C}\right.$ )

$t_{b} \quad$ Mean bulk temperature $\left({ }^{\circ} \mathrm{C}\right)$

$t_{i} \quad$ Inlet temperature of air into the heat exchanger $\left({ }^{\circ} \mathrm{C}\right)$

$t_{s} \quad$ Surface temperature of the heat exchanger tube $\left({ }^{\circ} \mathrm{C}\right)$

$\mathrm{v}_{\mathrm{a}} \quad$ Air velocity $(\mathrm{m} / \mathrm{s})$

$\rho_{\mathrm{a}} \quad$ Air density $\left(\mathrm{kg} / \mathrm{m}^{3}\right)$

\section{REFERENCES}

[1] Okoronkwo, C. A., Okwu, M. O., Ononogbo, C. and Ezurike B. 0. 2018. The Effect of Different Soil Feed Stock for the Development of a Soil Based Microbial Fuel Cell. American Journal of Earth Science and Engineering 1(2): 129-136.

[2] Ononogbo, C., Nwufo, O.C, Okoronkwo, C.A, Ogueke, N.V., Igbokwe, J.O. and Anyanwu, E.E. 2020. Equipment sizing and method for the application of exhaust gas waste heat to food crops drying using a hot air tray dryer. Indian Journal of Science and Technology 13(5): 502-518.

[3] Jadhao, J. S. and Thombare, D. G. 2013. Review on Exhaust Gas Heat Recovery for I.C. Engine. International Journal of 
Engineering and Innovative Technology 2(12): 93-100.

[4] Woolley, E., Yang, L. and Alessandro, S. 2018. Industrial waste heat recovery: A systematic approach. Sustainable Energy Technologies and Assessments 29: 50-59.

[5] Minxing, S. 2011. The feasibility of waste heat recovery and energy efficiency assessment in a steel plant. A Master Degree thesis, Clayton H. Riddell Faculty of Environment, Earth and Resources, Natural Resources Institute University of Manitoba Winnipeg, Manitoba-R3T 2N2.

[6] Jouhara, H., Navid, K., Sulaiman, A., Bertrand D., Amisha C., Savvas, A. T. 2018. Waste heat recovery technologies and applications. Thermal Science and Engineering Progress 6: 268-289.

[7] Nguyen, N.H., Lee, D.Y., Garud, K.S. and Lee, M.Y. 2021. Energy Saving Economic Evaluations of Exhaust Waste Heat Recovery Hot Water Supply System for Resort. Symmetry 13 (4): 624.

[8] Lee, M.Y., Seo, J.H., Lee, H.S. and Garud, K.S.2020. Power generation, efficiency and thermal stress of thermoelectric module with leg geometry, material, segmentation and two-stage arrangement. Symmetry 12: 786.

[9] Ononogbo, C., Nwufo, O.C. Nwakuba, N.R., Okoronkwo, C.A., Igbokwe, J.O.,and Anyanwu, E.E. 2021. Energy Consumption of Yam Slice Drying in an Exhaust Gas Waste Heat Recovery Hot Air Tray Dryer. Scientific Research Journal 9 (8): 1-7.

[10] Tiwari, G. N. 2012. Solar Energy Fundamentals, Design, Modelling and Application. Narosa Publishing House PVT Ltd., New Delhi. Pp. 203 - 250.

[11] Antwi, K.N. 2007. Comparative Study of Hybrid Solar-Gas Crop Dryer. Unpublished M.Sc.Thesis. University of Cape Coast, Ghana. Pp. 10-25.

[12] Ehiem, J.C., Irtwange, S.V. and Obetta, S.E. 2009. Design and Development of an Industrial Fruit and Vegetable Dryer. Research Journal of Applied Sciences, Engineering and Technology 1(2): 44 -53.
[13] Beigi, M. 2016. Energy efficiency and moisture diffusivity of apple slices during convective drying. Food Sci. Technol, Campinas 36(1): 145-150.

[14] Onu, C. E., Igbokwe P. K. and Nwabanne J. T. 2017. Effective Moisture Diffusivity, Activation Energy and Specific Energy Consumption in the Thin-Layer Drying of Potato. International Journal of Novel Research in Engineering and Science 3(2): 10-22.

[15] Abbaszadeh, A., Motevali, A., Ghobadian, B., Khoshtaghaza, M. H., and Minaei, S. 2012, Effect of air velocity and temperature on energy and effective moisture diffusivity for Russian olive (Elaeugnusangastifolial) in thin-layer drying. Iran journal of chemistry and chemical engineering 31(1): 75-79.

[16] Ajala, A. S. and Abubakar, M. A. 2018. Study of drying kinetics and quality attributes of fermented corn grains as affected by drying temperatures and velocities. J Nutr Health Food Eng 8(2):205-212.

[17] Kılıç, E. E. and Çınar, I. 2019. Convective hot air drying characteristics of selected vegetables. International Advanced Researches and Engineering Journal 3(1): 7-13

[18] Rajput, R.K. 2010. Heat and Mass Transfer in S. I. Units. 3 ${ }^{\text {rd }}$ Ed. S. Chand and Company Ltd. Ram Nagar, New Delhi-110 055.

[19] Rao, S. G., Sharma, K.V. Chary,S.P., Bakar, R.A. Rahman, K.,Kadirgama, M. M.and Noor, M.M.. 2011. Experimental Study on Heat Transfer Coefficient and Friction Factor of $\mathrm{Al}_{2} \mathrm{O}_{3} \mathrm{Nanofluid}$ in a Packed Bed Column. 1: 1-15.

[20] Eastop, T. D. andMacConkey, A. (1999). Applied Thermodynamics for Engineering Technologists. Pearson Education Ltd. 5th edn. 11,Panchsheel Park, New Delhi, India. Pp.619.

[21] Ononogbo, C., Nwufo, O.C., Nwakuba, N.R., Okoronkwo, C.A., Igbokwe, J.O., Nwadinobi, P.C. and Anyanwu, E.E. 2021. Energy parameters of corn drying in a hot air dryer powered by exhaust gas waste heat: an optimization case study of the food-energy nexus. Energy Nexus 4: 1-8. 